\title{
OBSERVATIONS ON THE IMPORTANCE OF THE American Revolution, AND THE MEANS OF MAKING IT A BENEFIT TO THE WORLD
}

\author{
BY RICHARD PRICE, D.D.LL.D.
}

HE Rev. Dr. Price (I723-I79I), a Unitarian minister in
London, had published his Observations in England in
I 785 , the same year an American edition appeared in Trenton, New Jersey. The following passages are excerpted from a copy in the library's Special Collections. Rev. Price, who also hailed the glories of the French Revolution, became the "villain" in Edmund Burke's Reflections on the Revolution in France, published in 1790.

\section{Of PEACE, And the Means of perpetuating it}

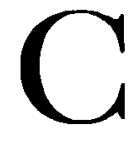

IVILE Government is an expedient for collecting the wisdom and the force of a community of confederacy, to preserve its peace and liberty against every hostile invasion, whether from within or from without. In the latter of these respects, the United States are happily secured; but they are far from being equally happy in the former respect. Having now, in consequence of their successful resistance of the invasion of Britain, united to their remoteness from Europe, no external enemy to fear, they are in danger of fighting with one another. This is the greatest danger; and providing securities against it is their hardest work. Should they fail in this, America may some time or other be turned into a scene of blood; and instead of being the hope and refuge of the world, may become a terror to it.

When a dispute arises among individuals in a State, an appeal is made to a court of law; that is, to the wisdom and justice of the State. The court decides. The losing party acquiesces; or, if he does not, the power of the State forces him to submission; and thus the effects of contention are suppressed, and peace is maintained. In a way similar to this, peace may be maintained between any number of confederated States; and I can almost imagine, that it is not impossible but that 
by some such means universal peace may some time or other be produced, and all war excluded from the world. Why may we not hope to see this begun in America? The articles of confederation make considerable advances towards it. When a dispute arises between any of the States, they order an appeal to Congress, an enquiry by Congress, a hearing, and a decision. But here they stop. What is most of all necessary is omitted. No provision is made for enforcing the decisions of Congress; and this renders them inefficient and futile. I am by no means qualified to point out the best method of removing this defect. Much must be given up for this purpose, nor is it easy to give up too much. Without all doubt the powers of Congress must be enlarged. In particular, a power must be given it to collect, on certain emergencies, the force of the confederacy, and to employ it in carrying its decisions into execution. A State against which a decision is made, will yield of course when it knows that such a force exists, and that it allows no hope from resistance.

By this force I do not mean a STANDING ARMY. God forbid, that standing armies should ever find an establishment in America. They are every where the grand supports of arbitrary power, and the chief causes of the depression of mankind. No wise people will trust their defence out of their own hands, or consent to hold their rights at the mercy of armed slaves. Free States ought to be bodies of armed citizens, well regulated, and well disciplined, and always ready to turn out, when properly called upon, to execute the laws, to quell riots, and to keep the peace. Such, if I am rightly informed, are the citizens of America. Why then may not CONGRESS be furnished with a power of calling out from the confederated States, quotas of militia sufficient to force at once the compliance of any State which may shew an inclination to break the union by resisting its decisions?

I am very sensible that it will be difficult to guard such a power against abuse; and, perhaps, better means of answering this end are discoverable. In human affairs, however, the choice generally offered us, is "of two evils to take the least." We choose the restraint of civil government, because a less evil than anarchy; and, in like manner, in the present instance, the danger of the abuse of power, and of its being employed sometimes to enforce wrong decisions, must be submitted to, because a less evil than the misery of intestine wars. Much, however, may be done to lessen this danger. Such regulations 
as those in the ninth of the articles of confederation will, in a great measure, prevent hasty and partial decisions. The rotation established by the fifth article will prevent that corruption of character which seldom fails to be produced by the long possession of power; and the right reserved to every state of recalling its Delegates when dissatisfied with them, will keep them constantly responsible and cautious.

The observations now made must be extended to money transactions. Congress must be trusted with a power of procuring supplies for defraying the expenses of the confederation; of contracting debts, and providing funds for discharging them: and this power must not be capable of being defeated by the opposition of any minority of the States.

In short, the credit of the United States, their strength, their respectableness abroad, their liberty at home, and even their existence depend on the preservation of a firm political union; and such an union cannot be preserved, without giving all possible weight and energy to the authority of that delegation which constitutes the union.

Would it not be proper to take periodical surveys of the different states, their numbers of both sexes in every stage of life, their condition, occupations, property, \&c.? Would not such surveys, in conjunction with accurate registers of births, marriages and deaths at all ages, afford much important instruction by shewing what laws govern human mortality, and what situations, employments, and civil institutions, are most favourable to the health and happiness of mankind? Would they not keep constantly in view the progress of population in the states, and the increase or decline of their resources? But more especially, are they not the only means of procuring the necessary information for determining accurately and equitably the proportions of men and money to be contributed by each state for supporting and strengthening the confederation?

\section{Of LIBERTY}

THE next point I would insist on, as an object of supreme importance, is the establishment of such a system of perfect

1 liberty, religious as well as civil, in America, as shall render it a country where truth and reason shall have fair play, and the 
human powers find full scope for exerting themselves, and for shewing how far they can carry human improvement.

The faculties of man have hitherto, in all countries, been more or less cramped by the interference of civil authority in matters of speculation, by tyrannical laws against heresy and schism, and by slavish hierarchies and religious establishments. It is above all things desirable that no such fetters on reason should be admitted into America. I observe, with inexpressible satisfaction, that at present they have no existence there. In this respect the governments of the United States are liberal to a degree that is unparalleled. They have the distinguished honour of being the first states under heaven in which forms of government have been established favourable to universal liberty. They have been thus distinguished in their infancy. What then will they be in a more advanced state; when time and experience, and the concurring assistance of the wise and virtuous, in every part of the earth, shall have introduced into the new governments, corrections and amendments which will render them still more friendly to liberty, and more the means of promoting human happiness and dignity? May we not there see the dawning of brighter days on earth, and a new creation rising? But I must check myself. I am in danger of being carried too far by the ardour of my hopes.

The liberty I mean includes in it liberty of conduct in all civil matters-liberty of discussion in all speculative matters, and liberty of conscience in all religious matters. And it is then perfect, when under no restraint except when used to injure any one in his person, property or good name; that is, except when used to destroy itself.

In liberty of discussion, I include the liberty of examining all publick measures, and the conduct of all publick men; and of writing and publishing on all speculative and doctrinal points. 